\title{
FAKTOR-FAKTOR YANG MEMPENGARUHI KETERLAMBATAN LAPORAN PERTANGGUNGJAWABAN TERHADAP KUALITAS LKPD
}

\author{
Karolina Dahay \\ olindahay12@gmail.com
}

\begin{abstract}
Systems, Information Technology, and Government Accounting Standards. The study used is qualitative and quantitative data. The research used quantitative data analysis: instruments test classical assumption test, and multiple regression analysis. The results show that Human Resources competency and the application of Government Accounting Standards have a significant effect on the quality of local government reports. In contrast, Internal Control System and Information Technology do not have a considerable impact. Together all factors have a significant effect on the quality of LKPDLocal Government Reports.
\end{abstract}

Keywords: Human Resource Competency, SPI, IT Utilization, SAP Application, and LKPD Quality.

\section{PENDAHULUAN}

Akuntabilitas dan transparansi dalam pengelolaan keuangan pemerintah pusat dan daerah merupakan tujuan penting dalam reformasi akuntansi dan administrasi sektor publik. Salah satu pilar utama perekonomian daerah adalah akuntabilitas pemegang kekuasaan yang dipercaya dan bertanggung jawab dalam mengelola sumber daya publik yang disediakan oleh masyarakat dalam mendanai pembangunan dan menjalankan roda pemerintahan (Evicahyani \& Setiawina, 2016).

Sebagai upaya kongkrit dalam mewujudkan transparansi dan akuntabilitas pengelolaan keuangan pemerintah pusat dan daerah adalah dengan menyampaikan laporan pertanggungjawaban berupa laporan keuangan. Untuk memenuhi prinsip tepat waktu maka laporan keuangan pemerintah yang dihasilkan harus disusun sesuai dengan Standar Akuntansi Pemerintah yang berlaku umum. Tujuannya agar lebih akuntabel dan meningkatkan kualitas laporan keuangan (Arfianti, 2011).

Governmental Accounting Standard Board (1999) dalam Concepts Statement No. 1 tentang Objectives of Financial Reporting menyatakan bahwa akuntabilitas merupakan dasar dari pelaporan keuangan di pemerintah yang didasarkan pada hak masyarakat untuk 
mengetahui dan menerima penjelasan untuk pengumpulan sumber daya dan penggunaan pelaporan.

Pengelolaan keuangan pemerintah daerah harus dilaksanakan berdasarkan tata kelola yang baik (good governance), yaitu pengelolaan keuangan yang dilakukan secara transparan dan akuntabel, yang memungkinkan pengguna laporan keuangan dapat mengakses informasi tentang hasil yang dicapai dalam pemerintahan daerah (Sukmaningrum, 2012).

Masalah yang menjadi perhatian peneliti ialah menganalisis faktor kompetensi SDM, SPI dan penerapan SAP terhadap kualitas LKPD di pemerintah Kabupaten Keerom.

\section{Agency Theory}

\section{LANDASAN TEORI}

Teori agensi menjelaskan bahwa dalam pandangan principal agent model, pihak yang paling berkepentingan adalah pemilik capital asset (masyarakat) yang diserahkan kepada agent (pemerintah) yang harus dikendalikan setiap saat dan pengurus bertanggung jawab kepada owner.

Menurut Parananda (2016) menyatakan bahwa teori ini selain digunakan untuk tujuan pertanggungjawaban juga untuk menjelaskan hal-hal yang berkaitan dengan kesejahteraan (welfare), efisiensi (efficiency), akuntabilitas (accountability), informasi (information), dan modal (capital). Model ini sering digunakan dalam mengukur manfaat keuangan terhadap asset yang merupakan pelengkap indikator kinerja bukan laba atau mengukur manfaat dan penggunaan pelayanan lainnya.

\section{Internal Control System (SPI)}

Pengendalian internal adalah rencana yang mencakup struktur organisasi dan semua alat dan metode terkoordinasi yang digunakan dalam suatu organisasi dengan tujuan untuk mengamankan properti, memeriksa kebenaran dan keakuratan data akuntansi, mendorong efisiensi, dan patuh terhadap kebijakan manajemen yang telah ditetapkan (Coso report 2008) dalam Irsutami, Sinarti, \& Olifia (2018). 
Sistem pengendalian internal merupakan proses yang ditetapkan oleh suatu organisasi dan dijalankan oleh segenap anggota organisasi untuk memberikan kepercayaan yang memadai terhadap keandalan dari laporan keuangan, kepatuhan terhadap peraturan yang berlaku, efektifitas dan efisiensi operasional organisasi (Irsutami et al., 2018).

\section{Pemanfaatan Teknologi Informasi (PTI)}

Penggunaan teknologi informasi yang sesuai akan mendukung terwujudnya laporan keuangan yang berkualitas. Penelitian yang dilakukan Mustafa (2011) dalam Riandani (2017 memberikan bukti adanya pengaruh pemanfaatan TI terhadap keandalan dan ketepatan waktu pada laporan keuangan. Pemanfaatan teknologi informasi juga akan sangatmembantu mempercepat proses pengolahan data transaksi dan penyajian LKPD sehingga laporan keuangan tersebut tidak kehilangan nilai informasi salah satunya yaitu ketepatan waktu.

Teknologi informasi selain berfungsi sebagai teknologi komputer (hardware dan software) untuk pemrosesan dan penyimpanan informasi, juga memiliki fungsi sebagai alat komunikasi untuk penyampaian dan penyebaran informasi. Menurut Trisaputra (2013) Teknologi informasi sangat berperan penting dalam memberikan informasi yang berguna bagi para pengambil keputusan dalam suatu organisasi termasuk dalam hal pelaporan sehingga dapat membantu proses pengambilan keputusan secara lebih efektif.

\section{Penerapan Standar Akuntansi Pemerintah (SAP)}

Penerapan standar akuntansi pemerintahan menjamin bahwa laporan keuangan disusun sesuai dengan ketentuan yang berlaku, standar akuntansi pemerintahan merupakan standar yang menjadi acuan atau pedoman yang menjamin penyusunan laporan keuangan yang memenuhi kualifikasi informasi keuangan yang berguna untuk penggunanya dan informasi tersebut merupakan indikator bahwa laporan keuangan memenuhi kualifikasi informasi (Permadi, 2013).

Peraturan Pemerintah Nomor 71 Tahun 2010 tentang Standar Akuntansi Pemerintahan Pasal 1 menyatakan bahwa akuntansi adalah proses pencatatan, pengukuran, 
pengklasifikasian, peringkasan transaksi dan peristiwa keuangan, penafsiran hasil, dan penyajian laporan.

Standar Akuntansi Pemerintah (SAP) adalah prinsip-prinsip akuntansi yang diterapkan dalam menyusun dan menyajikan laporan keuangan pemerintah. Standar Akuntansi Pemerintahan tersebut dibutuhkan dalam rangka penyusunan laporan pertanggungjawaban pelaksanaan APBN/APBD berupa laporan keuangan yang setidaknya meliputi Laporan Realisasi Anggaran, Laporan Perubahan Saldo Anggaran Lebih, Neraca, Laporan Operasional, Laporan Arus Kas, Laporan Perubahan Ekuitas dan Catatan atas Laporan Keuangan.

Model Penelitian

\section{Gambar 1 \\ Model Penelitian}

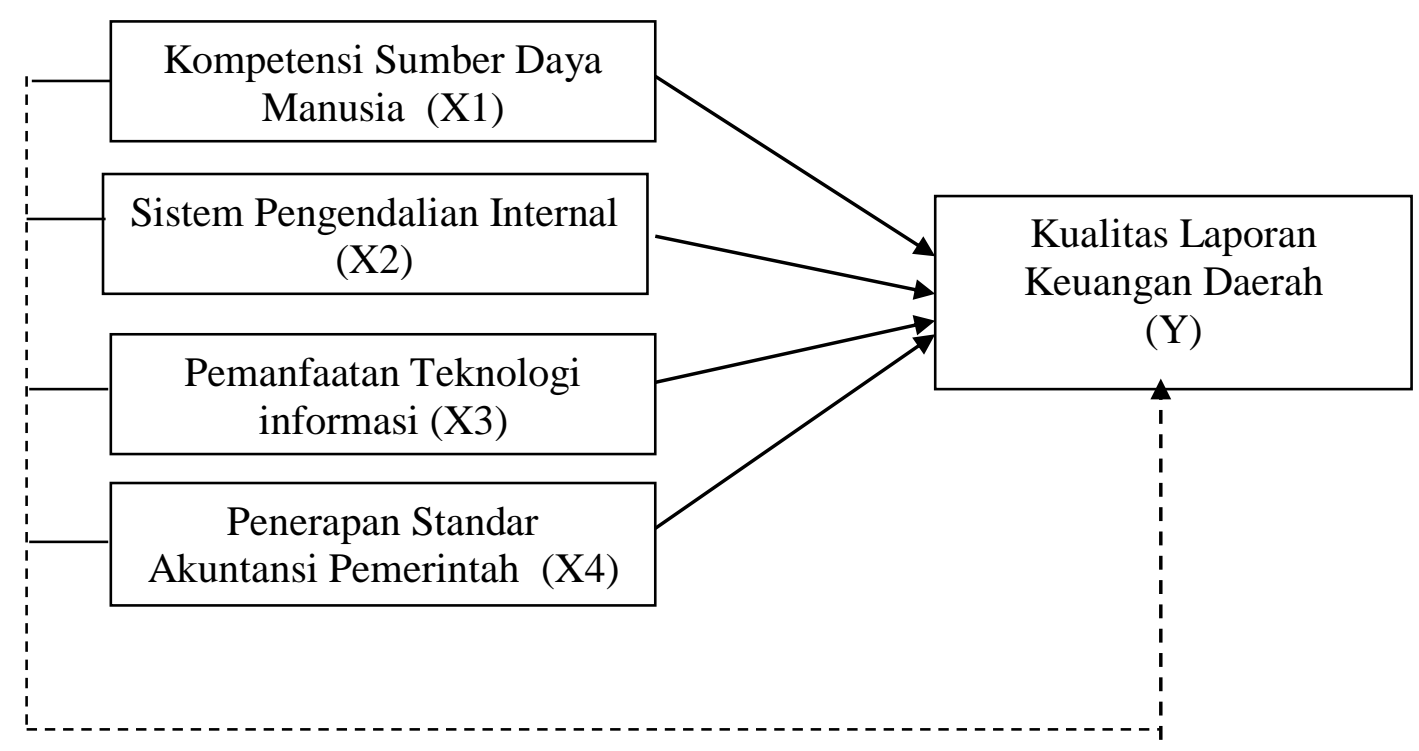

Sumber : Penulis, 2019

Keterangan :

= Hubungan parsial

= Hubungan simultan 


\section{METODE PENELITIAN}

\section{Lokasi Penelitian}

Lokasi penelitian ini akan dilaksanakan pada seluruh SKPD (Dinas, Badan, Kantor, dan bagian keuangan) pada Pemerintah Kabupaten Keerom. Pemilihan lokasi ini ditetapkan berkaitan dengan keterbatasan waktu pelaksanaan penelitian diluar Pemerintah Kabupaten Keerom serta diharapkan bahwa dengan lokasi penelitian ini dapat menjakau seluruh SKPD yang ada pada pemerintah Kabupaten Keerom sehingga dapat mempermudah penulis dalam pengumpulan data sesuai masalah yang ditetapkan.

\section{Jenis dan Sumber Data}

Adapun jenis data yang akan digunakan adalah data kuantitatif dan kualitatif. Data kuantitatif yang berupa nilai atau skor atas jawaban yang diberikan oleh responden terhadap pertanyaan-pertanyaan yang ada dalam kuesioner. Data kualitatif berupa wawancara dan penelitian kepustakaan. Sedangkan sumber data adalah data primer yang diterima secara langsung dari sumber lokasi penelitian atau sumber asli tanpa melalui pihak perantara.

Penelitian ini menggunakan data primer yang dapat diterima secara langsung dari responden dengan menggunakan kuisioner atau daftar pertanyaan sebagai alat untuk mengumpulkan data, dan dilengkapi dengan data lainnya yang berkaitan dengan masalah penelitian. Kemudian menggunakan data sekunder yaitu data yang diterima peneliti secara tidak langsung melalui media perantara (diperoleh dan dicatat oleh pihak lain).

\section{Definisi Operasional}

\section{Kompetensi SDM}

Kompetensi sumber daya manusia adalah keahlian dan ciri khas yang dimiliki oleh seseorang baik Pegawai Negeri Sipil maupun karyawan untuk melaksanakan tugas dan tanggungjawab yang diembannya berdasarkan pengetahuan dan pengalaman yang dimiliki. Indikatornya adalah pengetahuan, keterampilan dan sikap perilaku.

\section{Sistem Pengendalian intern (SPI)}


Sistem pengendalian intern adalah suatu proses yang dipengaruhi oleh manajeman yang diciptakan untuk memberikan keyakinan yang memadai dalam penciptaan efektivitas, efisiensi, ketaatan terhadap peraturan perundang-undangan yang berlaku dan keandalan penyajian keuangan daerah. Indikator yang dikembangkan untuk menjelaskan Pengendalian Intern dalam penelitian ini sumbernya di ambil dari Permendagri Nomor 4 Tahun 2008 Pedoman Pelaksanaan Reviu Atas LKPD sebagai berikut :

1. Efektivitas,

2. Efisiensi,

3. Kepatuhan terhadap peraturan perundang-undangan yang berlaku,

4. Penyajian keuangan yang andal

\section{Pemanfaatan teknologi informasi}

Pemanfaatan teknologi informasi adalah sarana yang digunakan untuk menyediakan informasi yang bermanfaat bagi para pengambil keputusan di dalam organisasi termasuk dalam hal pelaporan sehingga dapat membantu proses pengambilan keputusan dengan lebih efektif. Indikator yang dikembangkan untuk menjelaskan Pemanfaatan teknologi informasi dalam penelitian ini sumbernya Efendi, Darwanis, \& Abdullah (2017) adalah Perangkat, Pengelolaan dan penyimpanan data keuangan, Perawatan dan pemeliharaan pada peangkat komputer.

\section{Penerapan SAP}

Penerapan asas yang baik dalam mengelola keuangan negara juga menetapkan asas akuntabilitas yang berorientasi pada hasil, profesionalisme, proporsionalitas, transparansi dalam pengelolaan keuangan, dan pemeriksaan oleh lembaga audit yang independen dan berdiri sendiri. Standar akuntansi pemerintahan merupakan prinsip akuntansi yang diharapkan dalam menyusun dan menyajikan laporan keuangan pemerintah baik di pusat maupun di daerah.

Secara praktek pelaporan keuangan dalam suatu organisasi sektor publik adalah konsep yang didasarkan pada teori keagenan. Dalam hal pelaporan keuangan, pemerintah yang bertindak sebagai agen wajib memberikan informasi yang berguna kepada pengguna 
informasi keuangan pemerintah, yang bertindak sebagai prinsipal dalam menilai akuntabilitas dan pengambilan keputusan, baik keputusan ekonomi, sosial atau politik secara tidak langsung maupun secara langsung melalui perwakilannya.

\section{Kualitas laporan keuangan Pemerintah Daerah}

Adapun laporan keuangan dapat dikatakan sudah berkualitas jika bisa memenuhi beberapa syarat karakteristik-karakteristik kualitas sesuai dengan yang tertuang dalam PP.71 Tahun 2010 Tentang Standar Akuntansi Pemerintah yaitu relevan, andal, dapat dibandingkan, dan dapat dipahami. Pada Paragraf ketiga juga menyebutkan bahwa setiap entitas pelaporan berkewajiban dalam melaporkan apa yang sudah dilakukan serta hasil yang dicapai dalam pelaksanaan kegiatan secara tersusun dan sistematis dalam periode pelaporan untuk kepentingan sebagai berikut:

1. Akuntanbilitas,

2. Manajemen,

3. Transparansi, dan

4. Keserasian antar generasi.

\section{Instrumen Penelitian dan Pengujian Instrumen}

Dua syarat yang harus dipenuhi untuk menguji data, yaitu valid dan realibel. Validitas adalah suatu ukuran yang menunjukkan tingkatan kesalahan atau kevalidan suatu instrumen (Arikunto 1998;160) yang menyampaikan bahwa instrumen dikatakan valid apabila mampu mengukur apa yang diinginkan; apabila dapat mengungkapkan data variabel yang diteliti secara tepat. Menurut Sugiyono (2010: 3) reliabilitas adalah derajat konsistensi atau keajegan data dalam interval waktu tertentu. Uji reliabilitas digunakan untuk mengetahui sejauh mana hasil pengukuran tetap konsisten bila dilakukan pengukuran beberapa kali dengan gejala yang sama.

\section{Metode Pengumpulan Data}

Penelitian kepustakaan (library research), yaitu penelitian yang dilakukan dengan mempelajari teori dan konsep yang sehubungan dengan masalah yang diteliti pada buku, 
literatur, ataupun artikel akuntansi, guna memperoleh landasan teoritis untuk melakukan pembahasan yang ada kaitannya dengan masalah yang menjadi kajian dalam penelitian ini baik yang bersumber dari buku-buku literatur, jurnal ilmiah maupun peraturan perundangundangan guna memperkuat kajian dalam penelitian ini.

Kuesioner merupakan teknik pengumpulan data yang dilakukan dengan cara memberi seperangkat pertanyaan atau pernyataan tertulis kepada responden untuk dijawabnya (Sugiyono, 2013:142). Data dikumpulkan dengan menggunakan metode kuesioner yaitu dengan memberikan daftar pertanyaan atau kuesioner secara langsung kepada para responden. pertanyaan - pertanyaan dalam angket tertutup dibuat dengan menggunakan skala dengan nilai atau skor 1-5 misalnya untuk kategori pertanyaan dengan jawaban sangat tidak setuju $(\mathrm{STS})=1$, tidak setuju $(\mathrm{TS})=2$, ragu-ragu $(\mathrm{RR})=3$, setuju $(\mathrm{S})=4$ dan sangat setuju (ST) $=5$

\section{Populasi dan Sampel}

Populasi dalam penelitian ini adalah seluruh SKPD pada Pemda Kabupaten Keerom. Pemilihan sampel menggunakan purposive sampling method. Purposive sampling method bertujuan yaitu sampel dipilih berdasarkan kriteria tertentu. Kriteria yang digunakan adalah berdasarkan pertimbangan (judgment), sehingga disebut sebagai judgment sampling. Adapun kriteria yang digunakan dalam pengambilan sampel ini adalah pada bagian keuangan setiap SKPD di Pemerintah Daerah Kabupaten Keerom yaitu yang terdiri dari Kasubag dan bendahara Keuangan. Setiap SKPD sampel yang dipilih adalah sebanyak 2 orang. Jadi jumlah seluruh sampel pada 41 SKPD yang ada di Pemerinta Daerah Kabupaten Keerom adalah sebanyak 82 orang.

\section{Teknik Analisis Data}

Sebelum melakukan pengujian analisis regresi berganda terlebih dahulu harus lolos uji asumsi klasik. Uji asumsi klasik digunakan untuk melihat apakah di dalam model regresi tersebut terdapat suatu penyimpangan, sehingga syarat-syarat yang harus dipenuhi adalah Uji asumsi klasik terdiri dari uji normalitas, uji multikolinieritas, dan uji heterokesdatisitas. 
Analisis Regresi Berganda Untuk mengukur Faktor-faktor yang mempengaruhi keterlambatan laporan pertanggungjawaban terhadap kualitas LKPD di Kabupaten Keerom maka, analisis regresi berganda (multiple regression) digunakan karena dalam penelitian ini mempunyai 4 (empat) variabel dependen sebagai preditor yang akan berpengaruh terhadap variabel independen yakni dengan model Statistik sebagai berikut: (Ghozali, 2006)

$$
Y_{i}=\beta_{0}+\beta_{1} X_{1}+\beta_{2} X_{2}+\beta_{3} X_{3}+\beta_{4} X_{4}+e
$$

dimana:

$$
\begin{array}{ll}
\mathrm{Y} & =\text { Kualitas Laporan Keuangan } \\
\mathrm{X}_{1} & =\text { Kompetensi SDM } \\
\mathrm{X}_{2} & =\text { Sistem pengendalian Internal } \\
\mathrm{X}_{3} & =\text { Pemanfaatan teknologi Informasi } \\
\mathrm{X}_{4} & =\text { Penerapan SAP } \\
\beta_{0} & =\text { Intercept }
\end{array}
$$

$\beta_{1}, \beta_{2}, \beta_{3}, \beta_{4}=$ Koefisien regresi yang menggambarkan pengaruh variabel $X_{1}, X_{2}, X_{3}, X_{4}$ terhadap $Y$.

$$
\mathrm{e} \quad=\text { Faktor eror }
$$

\section{Pengujian Hipotesis}

Pengujian hipotesis dari Faktor-faktor yang mempengaruhi keterlambatan laporan pertanggungjawaban terhadap kualitas LKPD Kabupaten Keerom digunakan uji F dan uji t.

1. Uji secara parsial (Uji t)

Uji statistik $\mathrm{t}$ dipakai untuk menunjukkan seberapa jauh pengaruh satu variabel penjelas/independen secara individual dalam menerangkan variasi variabel dependen (Ghozali, 2016). Cara melakukan uji t adalah sebagai berikut:

a. Membandingkan hasil besarnya peluang melakukan kesalahan (tingkat signifikansi) yang muncul, dengan tingkat peluang munculnya kejadian (probabilitas) yang ditentukan sebesar $5 \%$ atau 0,05 pada output: 
1. Apabila signifikansi $>0.05$ maka keputusannya adalah menerima Ho dan menolak Ha

2. Apabila signifikansi $<0.05$ maka keputusannya adalah menolak Ho dan menerima $\mathrm{Ha}$

b. Membandingkan nilai statistik $t$ hitung dengan nilai statistik $\mathrm{t}$ tabel:

1. Apabila nilai statistik t hitung < nilai statistik tabel, maka Ho diterima

2. Apabila nilai statistik t hitung $>$ nilai statistik tabel, maka Ho ditolak.

2. Secara Simultan (Uji F)

Uji statistik F pada dasarnya menunjukkan apakah semua variabel independen atau bebas yang dimasukkan berpengaruh secara bersama- sama terhadap variabel dependen atau terikat (Ghozali, 2016). Cara pengujiannya adalah berdasarkan probabilitas. Bila probabilitas lebih besar daripada $0,05(\alpha)$, maka variabel bebas secara serentak tidak berpengaruh variabel terikat. Sedangkan bila probabilitas lebih kecil daripada 0,05 ( $\alpha$ ), maka variabel bebas secara serentak berpengaruh terhadap variabel terikat. Besarnya a yang digunakan dalam penelitian ini adalah sebesar $5 \%$. Adapun kriteria penilaiannya sebagai berikut:

$\mathrm{F}$ hitung > F tabel, maka hipotesis nol $(\mathrm{Ho})$ ditolak

$\mathrm{F}$ hitung $<\mathrm{F}$ tabel, maka hipotesis nol $(\mathrm{Ho})$ diterima.

HASIL PENELITIAN DAN PEMBAHASAN

\section{Hasil Uji Validitas dan Reliabilitas}

Tabel 1

Rekapitulasi Hasil Uji Validitas dan Reliabilitas Instrumen

\begin{tabular}{|c|c|c|c|c|c|c|}
\hline Variabel & Pernyataan & $\begin{array}{c}\text { Nilai } \\
\mathrm{r}_{\text {hitung }}\end{array}$ & $\begin{array}{c}\text { Nilai } \\
\mathrm{r}_{\text {tabel }}\end{array}$ & Hasil & $\begin{array}{c}\text { Cronbach' } \\
\text { s Alpha }\end{array}$ & Hasil \\
\hline \multirow{5}{*}{ X1 } & 1 & 0,644 & 0,215 & Valid & & \\
\cline { 2 - 5 } & 2 & 0,593 & 0,215 & Valid & & \\
\cline { 2 - 5 } & 3 & 0,595 & 0,215 & Valid & \multirow{2}{*}{0,744} & Reliabel \\
\cline { 2 - 5 } & 4 & 0,478 & 0,215 & Valid & & \\
\cline { 2 - 5 } & 5 & 0,742 & 0,215 & Valid & & \\
\cline { 2 - 5 } & 6 & 0,612 & 0,215 & Valid & & Reliabel \\
\hline
\end{tabular}




\begin{tabular}{|c|c|c|c|c|c|c|}
\hline Variabel & Pernyataan & $\begin{array}{l}\text { Nilai } \\
r_{\text {hitung }}\end{array}$ & $\begin{array}{l}\text { Nilai } \\
r_{\text {tabel }}\end{array}$ & Hasil & $\begin{array}{c}\text { Cronbach' } \\
\text { s Alpha }\end{array}$ & Hasil \\
\hline & 2 & 0,337 & 0,215 & Valid & & \\
\hline & 3 & 0,304 & 0,215 & Valid & & \\
\hline & 4 & 0,445 & 0,215 & Valid & & \\
\hline & 5 & 0,554 & 0,215 & Valid & & \\
\hline & 6 & 0,555 & 0,215 & Valid & & \\
\hline \multirow{6}{*}{ X3 } & 1 & 0,575 & 0,215 & Valid & \multirow{6}{*}{0,777} & \multirow{6}{*}{ Reliabe } \\
\hline & 2 & 0,536 & 0,215 & Valid & & \\
\hline & 3 & 0,693 & 0,215 & Valid & & \\
\hline & 4 & 0,821 & 0,215 & Valid & & \\
\hline & 5 & 0,844 & 0,215 & Valid & & \\
\hline & 6 & 0,752 & 0,215 & Valid & & \\
\hline \multirow{6}{*}{ X4 } & 1 & 0,599 & 0,215 & Valid & \multirow{6}{*}{0,759} & \multirow{6}{*}{ Reliabe } \\
\hline & 2 & 0,535 & 0,215 & Valid & & \\
\hline & 3 & 0,780 & 0,215 & Valid & & \\
\hline & 4 & 0,807 & 0,215 & Valid & & \\
\hline & 5 & 0,756 & 0,215 & Valid & & \\
\hline & 6 & 0,400 & 0,215 & Valid & & \\
\hline \multirow{6}{*}{$Y$} & 1 & 0,741 & 0,215 & Valid & & \multirow{6}{*}{ Reliabe } \\
\hline & 2 & 0,280 & 0,215 & Valid & & \\
\hline & 3 & 0,394 & 0,215 & Valid & & \\
\hline & 4 & 0,673 & 0,215 & Valid & & \\
\hline & 5 & 0,524 & 0,215 & Valid & & \\
\hline & 6 & 0,387 & 0,215 & Valid & & \\
\hline
\end{tabular}

\section{Sumber : Data diolah, 2019}

Berdasarkan rekaputulasi hasil uji validitas dan reliabilitas instrumen pada tabel 1 diatas menunjukkan bahwa seluruh variabel penelitian adalah valid karena korelasi semua indikatornya lebih besar dari 0,215 dan cronbach alpha lebih besar dari 0,60 yang berarti semua item pernyataan yang dijadikan sebagai intrument dapat dipercaya keandalannya.

\section{Hasil Uji Normalitas}

Uji normalitas digunakan untuk menguji model regresi, apakah variabel independen memiliki distribusi normal atau tidak. Uji normalitas ini dapat dilihat dari distribusi pada grafik P-P plot berikut ini: 


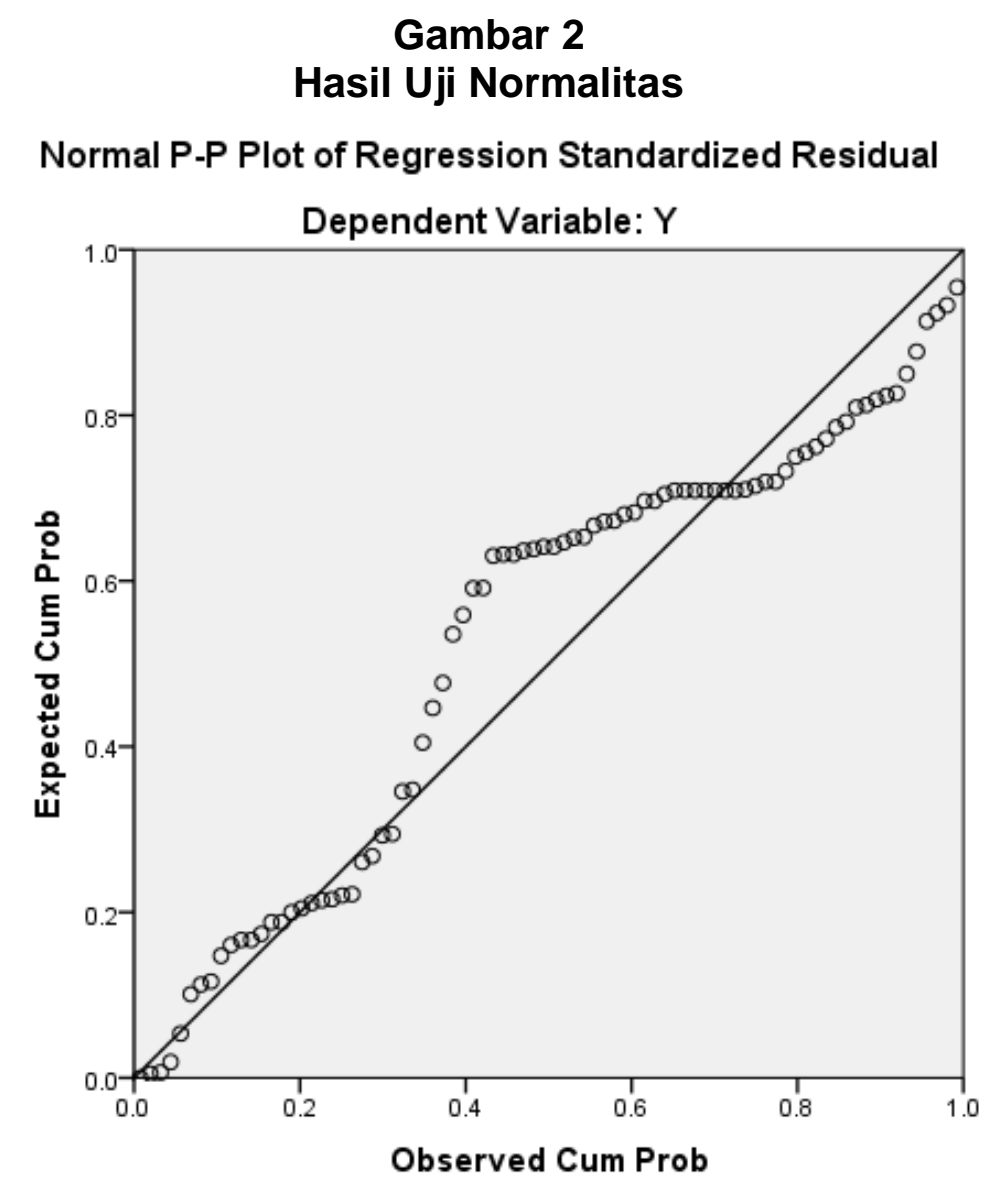

Sumber : Data diolah, 2019

Berdasarkan gambar diatas maka dapat dilihat bahwa data menyebar disekitar garis dan mengikuti arah garis diagonal pada grafik histogram tersebut, sehingga terjadi pola distribusi normal, Dengan demikian maka dapat disimpulkan bahwa model regresi memenuhi asumsi normalitas.

\section{Hasil Uji Multikolinieritas}

\section{Tabel 2}

\section{Hasil Pengujian Multikolinieritas}

\begin{tabular}{|l|c|c|}
\hline \multirow{2}{*}{ Variabel } & \multicolumn{2}{c|}{ Collinearity Statistics } \\
\cline { 2 - 3 } & Tolerance & VIF \\
\hline Kompetensi sumber daya manusia (X1) & 0,947 & 1,056 \\
\hline Sistem pengendalian internal (X2) & 0,852 & 1,173 \\
\hline Pemanfaatan teknologi informasi (X3) & 0,832 & 1,201 \\
\hline Penerapan standar akuntansi pemerintah (X4) & 0,771 & 1,296 \\
\hline
\end{tabular}

Sumber : Data Primer Diolah, 2019 
Berdasakan tabel diatas hasil pengujian multikolinieritas menunjukkan bahwa nilai tolerance mendekati 1 dan nilai VIF (Variance Inflation Factor) berada dibawah 10 yang berarti tidak terjadi multikolinieritas antar variabel independen dalam penelitian ini.

\section{Analisis Regresi Berganda}

Tabel 3

Hasil Analisis Regresi Berganda

\begin{tabular}{|c|c|c|c|c|c|c|}
\hline & \multicolumn{6}{|c|}{ Coefficients $^{a}$} \\
\hline \multirow{2}{*}{\multicolumn{2}{|c|}{ Model }} & \multicolumn{2}{|c|}{ Unstandardized Coefficients } & \multirow{2}{*}{$\begin{array}{c}\text { Standardized } \\
\text { Coefficients } \\
\text { Beta }\end{array}$} & \multirow[b]{2}{*}{$\mathrm{t}$} & \multirow[b]{2}{*}{ Sig. } \\
\hline & & $\mathrm{B}$ & Std. Error & & & \\
\hline \multirow[t]{5}{*}{1} & (Constant) & 26.616 & 1.688 & & 15.763 & .000 \\
\hline & $\mathrm{X} 1$ & .109 & .045 & .267 & 2.432 & .017 \\
\hline & $\mathrm{X} 2$ & -.033 & .036 & -.107 & -.926 & .357 \\
\hline & $\mathrm{X} 3$ & -.052 & .044 & -.137 & -1.170 & .246 \\
\hline & $\mathrm{X} 4$ & .077 & .037 & .255 & 2.094 & .040 \\
\hline
\end{tabular}

a. Dependent Variable: $Y$

Sumber : Data diolah, 2019

Berdasarkan tabel diatas hasil analisis regresi berganda yang dilakukan dengan bantuan program SPSS (Statistical Product and Service Solutions) diperoleh persamaan regresi sebagai berikut :

$$
Y=26,616+0,109 X_{1}-0,033 X_{2}-0,052 X_{3}+0,077 X_{3}+e
$$

Berdasarkan persamaan regresi yang diperoleh dari perhitungan diatas maka dapat dijelaskan pengaruh antara variabel kompetensi SDM $\left(\mathrm{X}_{1}\right)$, SPI (X2), dan pemanfaatan TI $\left(\mathrm{X}_{3}\right)$, dan penerapan SAP $\left(\mathrm{X}_{4}\right)$ terhadap kualitas LKPD $(\mathrm{Y})$. Untuk lebih jelasnya adalah sebagai berikut :

a. Nilai Konstanta $=26,616$

Nilai konstanta 26,616 menunjukkan bahwa apabila variabel kompetensi SDM $\left(\mathrm{X}_{1}\right)$, SPI (X2), pemanfaatan $\mathrm{TI}\left(\mathrm{X}_{3}\right)$, dan penerapan SAP $\left(\mathrm{X}_{4}\right)$ dalam kondisi tetap atau konstan, maka kualitas LKPD (Y) sebesar 26,616 satuan, yang berarti bahwa tanpa adanya variabel bebas yaitu kompetensi $\operatorname{SDM}\left(\mathrm{X}_{1}\right)$, SPI $(\mathrm{X} 2)$, dan pemanfaatan $\mathrm{TI}\left(\mathrm{X}_{3}\right)$, maka kualitas LKPD (Y) akan tetap berkurang sebesar -5,922.

b. Nilai $b_{1}=0,109$

Nilai $b_{1}$ menunjukkan nilai 0,109 dan memiliki tanda koefisien regresi yang positif, hal tersebut menunjukkan adanya pengaruh searah antara variabel kompetensi $\operatorname{SDM}\left(\mathrm{X}_{1}\right)$ 
dengan variabel kualitas LKPD $(Y)$ yang artinya bahwa apabila terjadi peningkatan atau kenaikan pada variabel kompetensi SDM $\left(\mathrm{X}_{1}\right)$ dengan asumsi bahwa variabel SPI (X2), pemanfaatan $\mathrm{TI}\left(\mathrm{X}_{3}\right)$, dan penerapan SAP $\left(\mathrm{X}_{4}\right)$ dalam kondisi tetap atau konstan, maka kualitas LKPD (Y) akan meningkat atau sebaliknya.

C. Nilai $b_{2}=-0,033$

Nilai $b_{2}$ menunjukkan nilai $-0,033$ dan memiliki tanda koefisien regresi yang negatif, hal tersebut menunjukkan tidak adanya pengaruh searah antara variabel sistem pengendalian internal (X2) dengan variabel kualitas LKPD (Y) yang artinya bahwa apabila terjadi penurunan atau pengurangan pada variabel sistem pengendalian internal (X2) dengan asumsi bahwa variabel kompetensi $\operatorname{SDM}\left(\mathrm{X}_{1}\right)$, pemanfaatan teknologi informasi $\left(X_{3}\right)$, dan pemanfaatan standar akutansi pemerintah $\left(X_{4}\right)$ dalam kondisi tetap atau konstan, maka kualitas LKPD $(Y)$ tetap mengalami peningkatan dan sebaliknya.

d. Nilai $b_{3}=-0,052$

Nilai $b_{3}$ menunjukkan nilai $-0,052$ dan memiliki tanda koefisien regresi yang negative, hal tersebut menunjukkan tidak adanya pengaruh searah antara variabel pemanfaatan teknologi informasi $\left(\mathrm{X}_{3}\right)$ dengan variabel kualitas LKPD $(\mathrm{Y})$ yang artinya bahwa apabila terjadi peningkatan atau kenaikan pada variabel pemanfaatan teknologi informasi $\left(\mathrm{X}_{3}\right)$ dengan asumsi bahwa variabel kompetensi $\operatorname{SDM}\left(\mathrm{X}_{1}\right)$, sistem pengendalian internal $(\mathrm{X} 2)$, dan pemanfaatan standar akutansi pemerintah $\left(\mathrm{X}_{4}\right)$ dalam kondisi tetap atau konstan, maka kualitas LKPD (Y) tetap akan mengalami peningkatan dan sebaliknya.

e. Nilai $b_{4}=0,077$

Nilai $b_{4}$ menunjukkan nilai 0,077 dan memiliki tanda koefisien regresi yang positif, hal tersebut menunjukkan adanya pengaruh searah antara variabel pemanfaatan standar akutansi pemerintah $\left(\mathrm{X}_{4}\right)$ dengan variabel kualitas LKPD $(\mathrm{Y})$ yang artinya bahwa apabila terjadi peningkatan atau kenaikan pada variabel penerapan SAP $\left(\mathrm{X}_{4}\right)$ dengan asumsi bahwa variabel kompetensi SDM (X1), sistem pengendalian internal (X2), dan pemanfaatan teknologi informasi $\left(\mathrm{X}_{3}\right)$ dalam kondisi tetap atau konstan, maka kualitas LKPD (Y) akan meningkat dan sebaliknya. 


\section{Hasil Uji T}

\section{Tabel 4}

Uji T

\begin{tabular}{|l|c|c|c|c|}
\hline \multicolumn{1}{|c|}{ Variabel } & $\mathrm{t}_{\text {hitung }}$ & $\mathrm{T}_{\text {tabel }}$ & Sig & Keterangan \\
\hline $\begin{array}{l}\text { Kompetensi sumber daya } \\
\text { manusia (X1) }\end{array}$ & 2,432 & 1,664 & 0,01 & Signifikan \\
\hline $\begin{array}{l}\text { Sistem pengendalian internal } \\
(\mathrm{X} 2)\end{array}$ & $-0,926$ & 1,664 & 0,35 & Tidak Signifikan \\
\hline $\begin{array}{l}\text { Pemanfaatan teknologi } \\
\text { informasi (X3) }\end{array}$ & $-1,170$ & 1,664 & 0,24 & Tidak Signifikan \\
\hline $\begin{array}{l}\text { Penerapan standar } \\
\text { akunatansi pemerintah (X4) }\end{array}$ & 2,094 & 1,664 & 0,04 & Signifikan \\
\hline
\end{tabular}

Sumber : Data diolah, 2019

Berdasarkan uji t sesuai dengan hasil pengujian, maka dapat dijelaskan sebagai berikut :

a. Pengaruh kompetensi SDM $\left(\mathrm{X}_{1}\right)$ terhadap kualitas LKPD (Y)

Pada tabel 4 menunjukkan nilai $t_{\text {hitung }}$ dari variabel kompetensi SDM $\left(X_{1}\right)$ yaitu 2,432 dan nilai $t_{\text {tabel }} 1,664$. Karena nilai $t_{\text {hitung }}>t_{\text {tabel }}$ yaitu 2,432 $>1,664$ dan memiliki taraf signifikansi sebesar $0,017<0,05$, maka Ho ditolak dan Hi diterima. Dapat disimpulkan bahwa kompetensi sumber daya manusia $\left(X_{1}\right)$ mempunyai pengaruh yang signifikan secara parsial terhadap kualitas LKPD Kabupaten Keerom.

b. Pengaruh sistem pengendalian internal (X2) terhadap kualitas LKPD (Y)

Pada tabel 4 menunjukkan nilai $t_{\text {hitung }}$ dari variabel $S P I\left(X_{2}\right)$ yaitu $-0,926$ dan nilai $t_{\text {tabel }}$ 1,664. Karena nilai $t_{\text {hitung }}<t_{\text {tabel }}$ yaitu $-0,926<1,664$ dan memiliki taraf signifikansi sebesar 0,357 > 0,05, maka Ho diterima dan Hi ditolak. Dapat disimpulkan bahwa sistem pengendalian internal (X2) tidak berpengaruh yang signifikan secara parsial terhadap kualitas LKPD Kabupaten Keerom.

c. Pengaruh pemanfaatan teknologi informasi $\left(\mathrm{X}_{3}\right)$ terhadap kualitas LKPD (Y)

Pada tabel 4 menunjukkan nilai $t_{\text {hitung }}$ dari variabel pemanfaatan teknologi informasi (X3) yaitu $-1,170$ dan nilai $t_{\text {tabel }} 1,664$. Karena nilai $t_{\text {hitung }}<t_{\text {tabel }}$ yaitu $-1,170<1,664$ dan memiliki taraf signifikansi sebesar 0,246 > 0,05, maka Ho diterima dan Hi ditolak. Dapat 
disimpulkan bahwa pemanfaatan teknologi informasi (X3) tidak berpengaruh yang signifikan secara parsial terhadap kualitas LKPD Kabupaten Keerom.

d. Pengaruh penerapan SAP $\left(\mathrm{X}_{4}\right)$ terhadap kualitas LKPD $(\mathrm{Y})$

Pada tabel 4 menunjukkan nilai $t_{\text {hitung }}$ untuk variabel penerapan SAP $\left(\mathrm{X}_{4}\right)$ yaitu 2,094 dan nilai $t_{\text {tabel }} 1,664$. Karena nilai $t_{\text {hitung }}>t_{\text {tabel }}$ yaitu 2,094 $>1,664$ dan memiliki taraf signifikansi sebesar $0,040<0,05$, maka Ho ditolak dan Hi diterima. Dapat disimpulkan bahwa penerapan standar akuntansi pemerintah $\left(\mathrm{X}_{1}\right)$ berpengaruh yang signifikan secara parsial terhadap kualitas LKPD Kabupaten Keerom.

Berdasarkan hasil uji t diatas menunjukkan bahwa variabel kompetensi SDM merupakan variabel yang paling menonjol pengaruhnya terhadap kualitas LKPD Kabupaten Keerom karena memiliki nilai $t_{\text {hitung }}$ yang lebih besar dibandingkan dengan nilai $t_{\text {hitung }}$ variabel SPI,PTI dan PSAP yaitu sebesar 2,432.

\section{Hasil Uji F}

\section{Tabel 5}

Uji F

\begin{tabular}{|ll|r|r|r|r|r|}
\hline \multicolumn{7}{|c|}{ ANOVA $^{\mathrm{a}}$} \\
\hline Model & & & & & \\
\hline 1 & Sum of Squares & Df & Mean Square & F & Sig. \\
& Regression & 4.174 & 4 & 1.043 & 2.666 & $.039^{\circ}$ \\
& Residual & 30.131 & 77 & .391 & & \\
& Total & 34.305 & 81 & & & \\
\hline
\end{tabular}

a. Dependent Variable: Y

b. Predictors: (Constant), X4, X1, X2, X3

\section{Sumber : Data diolah, 2019.}

Berdasarkan tabel 5 diatas dapat diketahui bahwa nilai $F_{\text {hitung }}$ adalah sebesar 2,666 dengan taraf signifikan sebesar 0,039. Selanjutnya untuk jumlah sampel sebanyak 82 sampel dan 4 variabel bebas yang diteliti, dapat diketahui bahwa besarnya nilai $F_{\text {tabel }}$ adalah sebesar 2,49. Karena nilai $F_{\text {hitung }}>F_{\text {tabel }}$ yaitu 2,666 $>2,49$ dan memiliki taraf signifikansi sebesar 0,039 yang lebih kecil dari 0,05, maka Ho ditolak dan Hi diterima. Dengan demikian dapat disimpulkan bahwa kompetensi SDM $\left(\mathrm{X}_{1}\right)$, SPI $(\mathrm{X} 2)$, pemanfaatan $\mathrm{TI}\left(\mathrm{X}_{3}\right)$, 
dan penerapan SAP (X4) berpengaruh secara simultan atau bersama-sama terhadap kualitas LKPD (Y) pada Pemerintah Daerah Kabupaten Keerom.

\section{Pembahasan}

\section{Pengaruh kompetensi SDM terhadap kualitas LKPD}

Sumber daya manusia merupakan faktor utama dalam peningkatan dalam sebuah organisasi. Kompetensi SDM merupakan kemampuan yang dimiliki oleh setiap pegawai dalam menyelesaikan tugas dan tanggung jawab yang di berikan. Sumber daya manusia dalam bekerja di lingkungan suatu organisasi harus diperlakukan dengan kualitas kehidupan kerja yang baik agar memungkinnya bekerja secara efektif, efisien, produktif, dan berkualitas Mangkunegara (2001) dalam Prabowo \& Nurdhiana (2012).

Berdasarkan hasil penelitian dan pengolahan data yang dilakukan menunjukkan bahwa nilai $t_{\text {hitung }}$ dari variabel kompetensi $\operatorname{SDM}\left(\mathrm{X}_{1}\right)$ yaitu 2,432 dan nilai $\mathrm{t}_{\text {tabel }} 1,664$. Karena nilai $t_{\text {hitung }}>t_{\text {tabel }}$ yaitu 2,432 $>1,664$ dan memiliki taraf signifikansi sebesar $0,017<0,05$, maka Ho ditolak dan $\mathrm{Hi}$ diterima. Dapat disimpulkan bahwa kompetensi $\operatorname{SDM}\left(\mathrm{X}_{1}\right)$ berpengaruh signifikan secara parsial terhadap kualitas LKPD pada Pemerintah Daerah Kabupaten Keerom.

Pemerintah Daerah Kabupaten Keerom, masih terdapat beberapa pegawai pada setiap SKPD pada bidang keuangan yang masih berlum mengerti betul tentang pembuatan laporan keuangan. Hal ini berdampak kepada keterlambatan laporan keuangan SKPD tersebut. Jika laporan keuangan SKPD lambat atau tidak memasukkan laporan keuangan paling lambat pada tanggal 10 bulan berjalan, maka akan mendapatkan sanksi berupa penundaan pencairan anggaran pada SKPD tersebut. hal ini juga berdampak kepada tidak maksimalnya kualitas LKPD.

Salah satu cara dalam mengatasi pegawai atau sumber daya manusia agar supaya lebih meningkatkan pengetahuan dalam pembuatan laporan keuangan yaitu dengan mengikuti pelatihan tentang laporan keuangan, agar supaya materi-materi tentang pembuatan laporan keuangan dapat dimengerti dan diaplikasikan pada pekerjaan. 


\section{Pengaruh SPI terhadap kualitas LKPD}

Sistem pengendalian internal dalam sebuah organisasi merupakan suatu sistem dalam mengendalikan manajemen dalam segala hal yang berhubungan dengan urusan organisasi.

Berdasarkan hasil penelitian dan pengolahan data, hasilnya menunjukkan bahwa nilai $t_{\text {hitung }}$ dari variabel SPI $\left(X_{2}\right)$ yaitu $-0,926$ dan nilai $t_{\text {tabel }} 1,664$. Karena nilai $t_{\text {hitung }}<t_{\text {tabel }}$ yaitu $0,926<1,664$ dan memiliki taraf signifikansi sebesar 0,357 > 0,05, maka Ho diterima dan Hi ditolak. Dapat disimpulkan bahwa SPI (X2) tidak memiliki pengaruh yang signifikan secara parsial terhadap kualitas LKPD di Kabupaten Keerom.

Pemerintah Kabupaten Keerom, masih terdapat beberapa SKPD yang pengendalian internnya masih kurang. Hal ini dapat dilihat dari laporan keuangan yang selalu saja tidak tepat waktu. Ini berarti SKPD tersebut masih kurang tegas menyikapi kewajiban organisasi. Hal ini berdampak kepada keterlambatannya penyusunan laporan bulan setiap bulannya. Ini menunjukkan kualitas LKPD tersebut masih kurang baik.

Untuk mengatasi SPI yang kurang baik pimpinan SKPD Pemerintah Kabupaten Keerom harus membuat kebijakan agar supaya prosedur pembuatan laporan keuangan setiap SKPD dapat berjalan dengan baik. Menurut Mulyadi (2002) tujuan pengendalian internal adalah untuk memberikan keyakinan yang memadai dalalam pencapaian tiga golongan yaitu :

1. Informasi keuangan yang Andal

2. Ketaatan terhadap peraturan dan hukum yang berlaku

3. Adanya efisiensi dan efektivitas dalam operasi

\section{Pengaruh pemanfaatan TI terhadap kualitas LKPD.}

Teknologi adalah suatu sarana yang digunakan dalam kegiatan operasional kantor dan merupakan sarana yang menunjang pekerjaan. Dengan adanya teknologi dapat memberikan kemudahan dalam melakukan pekerjaan dalam sebuah organisasi.

Berdasarkan hasil penelitian dan pengolahan data yang dilakukan menunjukkan bahwa nilai $t_{\text {hitung }}$ pemanfaatan $\mathrm{TI}(\mathrm{X} 3)$ yaitu $-1,170$ dan nilai $\mathrm{t}_{\text {tabel }} 1,664$. Karena nilai $\mathrm{t}_{\text {hitung }}<$ 
$t_{\text {tabel }}$ yaitu $-1,170<1,664$ dan memiliki taraf signifikansi sebesar 0,246 $>0,05$, maka Ho diterima dan Hi ditolak.

Dapat disimpulkan bahwa pemanfaatan teknologi informasi (X3) tidak berpengaruh terhadap kualitas LKPD pada Kabupaten Keerom karena masih terdapat beberapa SKPD yang pegawainya tidak lancar betul dalam menggunakan teknologi atau komputer dalam pembuatan laporan keuangan. Hal ini berdampak kepada keterlambatannya pembuatan laporan keuangan pada SKPD tersebut. Keterlambatan dalam pembuatan laporan keuangan berarti kinerja organisasi tersebut masih kurang baik.

Laporan keuangan merupakan suatu informasi yang menggambarkan keadaan dan kondisi dari laporan keuangan suatu organisasi dan informasi itu dapat dijadikan sebagai gambaran kinerja keuangan yang di capai organisasi tersebut (Fahmi, 2016). Tujuan dari membuat dan menyusun laporan keuangan menurut (Kasmir, 2016) adalah

1. Memberikan informasi tentang jenis dan jumlah aktiva (harta) yang dimiliki perusahaan pada saat ini.

2. Memberikan informasi tentang jenis dan jumlah kewajiban dan modal yang dimiliki perusahaan pada saat ini.

3. Memberikan informasi tentang jenis dan jumlah pendapatan yang diperoleh pada suatu periode tertentu.

4. Memberikan informasi tentang jumlah biaya dan jenis biaya yang dikeluarkan perusahaan dalam suatu periode tertentu.

5. Memberikan informasi tentang perubahaan-perubahan yang terjadi terhadap aktiva,pasiva dan modal perusahaan.

6. Memberikan informasi tentang kinerja manajemen perusahaan dalam suatu periode.

7. Memberikan informasi tentang catatan-catatan atas laporan keuangan.

8. Informasi keuangan lainnya.

\section{Pengaruh penerapan SAP terhadap kualitas LKPD.}

Standar akuntansi merupakan salah satu tolak ukur atau acuan dalam menyusun LKPD. Tujuannya agar supaya laporan keuangan bisa jelas dan terarah. Akuntansi 
pemerintah merupakan suatu aktifitas pemberian jasa untuk menyediakan informasi keuangan pemerintah berdasarkan proses pencatatatn, pengklasifikasian, pengikhtisaran, suatu transaksi keuangan pemerintah serta penafsiran atas informasi keuangan tersebut (Bahtiar, 2002).

Berdasarkan hasil penelitian dan analisis data, hasilnya menunjukkan bahwa nilai $t_{\text {hitung }}$ yaitu 2,094 dan nilai $t_{\text {tabel }} 1,664$. Karena nilai $t_{\text {hitung }}>t_{\text {tabel }}$ yaitu 2,094 $>1,664$ dan memiliki taraf signifikansi sebesar $0,040<0,05$, maka Ho ditolak dan Hi diterima. Dapat disimpulkan bahwa penerapan SAP $\left(\mathrm{X}_{1}\right)$ berpengaruh terhadap kualitas LKPD Pemerintah Kabupaten Keerom karena masih terdapat beberapa SKPD yang dalam membuat laporan keuangan tidak menerapkan standar akuntansi pemerintah. Hal ini disebabkan karena pegawai pada SKPD tersebut masih belum mengerti betul tentang SAP sehingga laporan keuangan yang dibuat selalu saja salah karena tidak mengacu kepada ketentuan yang berlaku.

\section{Pengaruh kompetensi SDM, SPI, pemanfaatan TI, dan penerapan SAP secara simultan terhadap kualitas LKPD}

Untuk memenuhi kebutuhan pengguna laporan keuangan harus memiliki kriteria yang relevan, andal, dapat dibandingkan, dapat dimengerti, tepat waktu, dan biaya/manfaat (Saidin, 2007).

Berdasarkan hasil penelitian dan pengolahan data hasilnya menunjukkan bahwa bahwa nilai $F_{\text {hitung }}$ adalah sebesar 2,666 dengan taraf signifikan sebesar 0,039. Selanjutnya untuk jumlah sampel sebanyak 82 sampel dan 4 variabel bebas yang diteliti, sehingga diketahui bahwa besarnya nilai $F_{\text {tabel }}$ adalah sebesar 2,49. Karena nilai $F_{\text {hitung }}>F_{\text {tabel }}$ yaitu 2,666 > 2,49 dan memiliki taraf signifikansi sebesar 0,039 yang lebih kecil dari 0,05, maka Ho ditolak dan Hi diterima. Dengan demikian dapat disimpulkan bahwa kompetensi SDM $\left(\mathrm{X}_{1}\right)$, SPI $(\mathrm{X} 2)$, pemanfaatan $\mathrm{TI}\left(\mathrm{X}_{3}\right)$, dan penerapan SAP $(\mathrm{X} 4)$ berpengaruh secara simultan atau bersama-sama terhadap kualitas LKPD (Y) Kabupaten Keerom.

Faktor yang paling dominan berpengaruh terhadap kualitas LKPD 
Laporan keuangan merupakan suatu hasil dari proses pengidentifikasian, pengukuran, pencatatan dari transaksi ekonomi (keuangan) dari entitas pemerintah yang dijadikan sebagai informasi dalam rangka pertanggungjawaban pengelolaan keuangan daerah dari pengambilan keputusan ekonomi oleh pihak-pihak eksternal entitas pemerintah daerah yang memerlukannya (Erlina, 2008)

Berdasarkan hasil penelitian dan pengolahan data yang dilakukan menunjukkan bahwa bahwa variabel yang paling dominan berpengaruh terhadap kualitas LKPD Kabupaten Keerom adalah variabel kompetensi SDM (X1) karena memiliki nilai thitung yang lebih besar dibandingkan dengan nilai $t_{\text {hitung }}$ variabel lainnya yaitu sebesar 2,432 .

\section{SIMPULAN}

Berdasarkan hasil pengujian dan pembahasan penelitian, maka dapat ditarik kesimpulan bahwa Kompetensi SDM berpengaruh signifikan terhadap kualitas LKPD, SPI tidak berpengaruh signifikan terhadap kualitas LKPD, Pemanfaatan TI tidak berpengaruh signifikan terhadap kualitas LKPD, Penerapan SAP berpengaruh yang signifikan terhadap LKPD. Sedangkan Kompetensi SDM, SPI, pemanfaatan TI, dan penerapan SAP secara bersama-sama (simultan) berpengaruh signifikan terhadap kualitas LKPD. Faktor yang paling menonjol untuk menguji kualitas LKPD pada pemerintah Kabuten Keerom adalah faktor kompetensi SDM.

Saran dalam penelitian ini adalah Kompetensi SDM harus benar-benar diterapkan sesuai dengan kebutuhan riil di daerah dan kompetensi pegawai, sebab sebagaimana yang ditengarai oleh penempatan yang tidak sesuai kompetensi masih memiliki banyak kelemahan mendasar, yang tergambar dari kualitas LKPDnya yang belum maksimal. Pegawai yang tidak memahami tentang pelaporan keuangan pada setiap SKPD di lingkung Pemerintah Daerah Kabupaten Keerom perlu diikutkan pelatihan tentang penyusunan laporan keuangan agar supaya bisa meningkatkan kualitas laporan keuangan setiap SKPD pada lingkup Pemerintah Daerah Kabupaten Keerom. Sistem Pengendalian Internal sebagai salah satu variabel yang dapat meningkatkan kualitas laporan keuangan masih perlu 
ditingkatkan dan dimasyarakatkan khususnya pada pemerintah kabupaten Keerom. Perlunya kebijakan-kebijakan pimpinan pada setiap SKPD khususnya pada pembuatan laporan keuangan agar supaya laporan keuangan dapat dibuat dengan baik. Pemanfaatan TI masih perlu secara terus menerus ditingkatkan agar dapat meningkatkan kualitas kerja yang lebih baik. Masih perlunya beberapa pegawai pada setiap SKPD di lingkup Pemerintah Daerah Kabupaten Keerom untuk diikutkan pelatihan khususnya dalam penggunaan teknologi dalam pembuatan laporan keuangan yang baik. Penerapan Standar Akuntansi perlu terus ditingkatkan untuk profesionalitas, proporsionalitas, keterbukaan dalam pengelolaan keuangan daerah. Perlunya peningkatan kualitas pegawai dalam penyusunan laporan keuangan yang harus sesuai dengan SAP agar supaya kualitas LKPD pada setiap SKPD pada lingkup Pemerintah Daerah Kabupaten Keerom bisa lebih baik lagi.

Keterbatasan Penelitian ini adalah dengan menggunakan kuisioner yaitu terkadang jawaban yang diberikan oleh responden atau sampel tidak menunjukkan keadaaan sesungguhnya. Sedangkan Faktor yang mempengaruhi keterlambatan laporan pertanggungjawaban keuangan pada lingkup Pemerintah Daerah Kabupaten Keerom masih banyak sedangkan penelitian ini hanya melihat dari pengaruh kompetensi SDM, SPI, pemanfaatan $\mathrm{TI}$, dan penerapan SAP.

\section{DAFTAR PUSTAKA}

Arfianti, D. (2011). Analisis Faktor-Faktor Yang Mempengaruhi Nilai Informasi Pelaporan Keuangan Pemerintah Daerah (Studi pada Satuan kerja Perangkat Daerah di Kabupaten Batang). Universitas Diponegoro.

Efendi, L., Darwanis, D., \& Abdullah, S. (2017). Faktor-Faktor Yang Mempengaruhi Kualitas Pelaporan Keuangan Daerah (Studi pada Satuan Kerja Perangkat Kabupaten Aceh Tengah). Jurnal Perspektif Ekonomi Darussalam, 3(2), 182-195. https://doi.org/10.24815/jped.v3i2.8230

Erlina. (2008). Metodologi Penelitian Bisnis untuk Akuntansi dan Manajemen (Kedua). Medan: USU Press.

Evicahyani, S. I., \& Setiawina, N. D. (2016). Analisis Faktor- faktor yang Mempengaruhi Kualitas Laporan Keuangan Pemerintah Daerah Kabupaten Tabanan. E-Jurnal Ekonomi Dan Bisnis Universitas Udayana 5.3 (2016) : 403-428, 3, 403-428.

Fahmi, I. (2016). Manajemen Sumber Daya Manusia, Teori dan Aplikasi. Alfabeta.

Ghozali, I. (2016). Aplikasi Analisis Multivariete Dengan Program IBM SPSS 23 (8th ed.). Badan Penerbit Universitas Diponegoro.

Irsutami, Sinarti, \& Olifia, J. (2018). Perancangan Sistem Pengendalian Internal Berbasis COSO pada Program Studi di Politeknik Negeri Batam ( Studi Kasus Prodi Akuntansi 
Manajerial , Jurusan Manajemen Bisnis ). Journal Of Applied Accounting and Taxation, 3(2), 150-157.

Kasmir. (2016). Analisis Laporan Keuangan (9, Ed.). PT RajaGrafindo Persada.

Parananda, B. H. (2016). Pengaruh Pemahaman Akuntansi, Tingkat Pendidikan, dan Lama Masa Kerja Terhadap Penerapan Sistem Akuntansi Pemerintah Daerah (SAPD) Pada Kabupaten Ngawi dan Kabupaten Pacitan. Jurnal Akuntansi Dan Bisnis, 16(1), 47-59.

Peraturan menteri Dalam Negeri Nomor 4 Tahun 2008 Pedoman Pelaksanaan Reviu Atas Laporan Keuangan Pemerintah Daerah. , (2008).

Peraturan Pemerintah Nomor 71 Tahun 2010 Tentang Standar Akuntansi Pemerintah. , (2010).

Permadi, A. D. (2013). Pengaruh Penerapan Sistem Akuntansi Keuangan Pemerintah Daerah Terhadap Kualitas Laporan Keuangan Pemerintah Daerah (Program Studi Akuntansi Fakultas Ekonomi Universitas Widyatama). Retrieved from http://repository.widyatama.ac.id/xmlui/handle/123456789/2327

Prabowo, P. A. S., \& Nurdhiana. (2012). Pengaruh Kemampuan Dan Motivasi Terhadap Kinerja Karyawan Akunting Pada Kantor Konsultan Pajak Pakar Penata Usaha Periode 2012 The Influence Of Ability And Motivation Accounting Employee Performance At Tax Consultant Firm Pakar Penata Usaha Period 2012. Sekolah Tinggi Ilmu Ekonomi Widya Manggala, 84-98.

Riandani, R. (2017). Pengaruh Kompetensi SDM, Pemanfaatan Teknologi Informasi, dan Pengendalian Intern terhadap Kualitas Laporan Keuangan (Studi Empiris Pada SKPD Kab. Limapuluh Kota ). Fakultas Ekonomi Universitas Negeri Padang, 4-28. Retrieved from http://ejournal.unp.ac.id/students/index.php/akt/article/view/2395

Sukmaningrum, T. (2012). Analisis Faktor Faktor yang Mempengaruhi Kualitas Informasi Laporan Keuangan Pemerintah Daerah. Fakultas Ekonomi dan Bisnis, Jurusan Akuntansi, Universitas Diponegoro.

Trisaputra, A. (2013). Pengaruh Pemanfaatan Teknologi Informasi dan Pengawasan Keuangan Daerah Terhadap Ketepatwaktuan Pelaporan Keuangan Pemerintah Daerah (Studi Empiris Pada SKPD Pemerintah Provinsi Sumatera Barat). Akuntansi, Universitas Negeri Padang. 